\title{
短報
}

\section{廣島縣の土地開 発}

西村嘉 助

近世以後における広島県の土地開発孝数枚の分布図によって概橎し，その時代的地 域的な相違老よ

1 集落の成立 近世以後に成立した集落で箨者の知り得たものを 3 期に分って 第 1 図に示す。第 1 期は明治維新以前，第 2 期は太平洋戦争前，第 3 期は戦後とする。 四によって先ず知り得ることは島璵㳂岸部を除いた山地部には近世以後成立の集落が 少いことである。即ち山地部の集落は殆ど全部が中世或はそれ以前に起源をるつとい

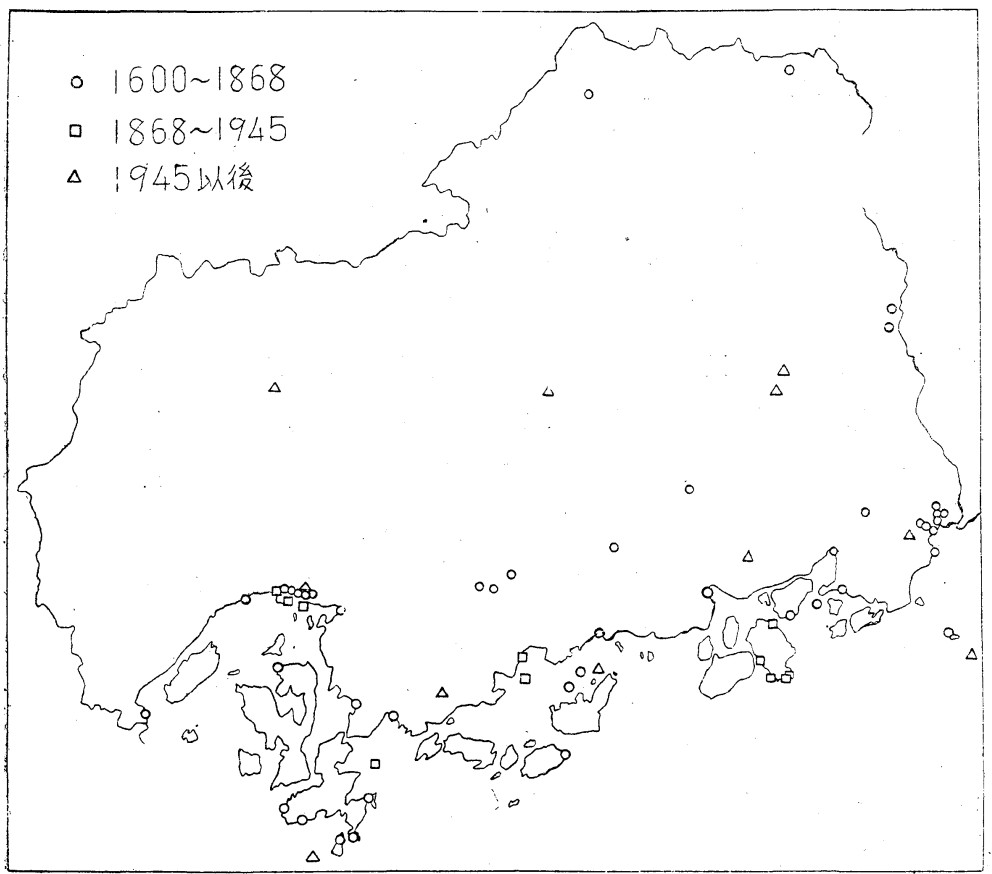

第1図集落の成立 
らことで岁っこれに反して島嶼沿岸部には近世以後成立の集落が多い。勿論記録に も明かなように島嶼沿岸部にも中世或はそれ以前に起源をもつものも多いのであるが， 山地部に比較すると比較的少数で, 新しい集落の比率が高い。以上のことは時期別に した 3 期を通じて同じ傾向を示しており，中世以前と近世以後との間には集落成立の 地域に大きな変化が岕ったことが分る。

近世成立の集落で最大なものはいうまでもなく広島であり，それにつぐものは福山 である。この 2 者において容易に分るように干拓によって新開の造成されたことが沿 岸部における集落の成立と深い関係がある。また沿岸部の集落には商業的な意味をる つものが多い。これも近世に抽いて瀬戸内海海上交通の進展と考え合せるならば，沿 岸島嶼部に括ける新しい集落の成立の幾分かが，全く商業的な意味によるるのを含ん でいることは容易に了解できる。全く港市として成立したものの例として御手洗・鹿 老渡を挙げれば充分であろう。広島・福山等の都书が商業的機能をるつていることは いうるでもない。近世成立の山地部の集落は多く間陌充塞的な意味をもつもので，農 業集落としてな既に他に比べて亜い立地条件のもとに成立した。これらのうちの二三 のものが典型的な街村の形態をるっていることは注目に值する。例えば比婆郡の三坂， 賀茂郡の十文字・三升原等である。

明治以後の第 2 期に成立した集落は大体島興沿岸部に限られており，農業地域の間 㩐充塞的なるの妓び都市化の拡張部としてのものが多い。瀨戸内海の商品農業化に従 って新しい耗地の開䇪が進み, 集落の出来得る間隚には新しい集落が成立した。瀬戸 内海の島踾部が人口過㮃に転じたのはこの時期からである。

戦後の第 3 期の新集落はすべて開拓団といら形で行われたもので，山地部において も数個の新しい農村ができたし，沿岸島橿部においても多数の開拓農村が成立した。 これらの村は周辺の村々に比べれば立地条件が悪く，競争的位置において存続せしめ る為にはハンディキヤップを資本的に技術的に埋める必要がある。

各個の集落の開発については既に各種の研究もあり，筆者も三三のものについて調 查を行っているので詳細ば後報する予定である。

2 石高・耕地面皘の增加 新成立の集落については前節で概観したが，一般的 にどのような地域に土地開発が進展したか，主として石高・耕地面積の増加によって 概観し上うと思う。 


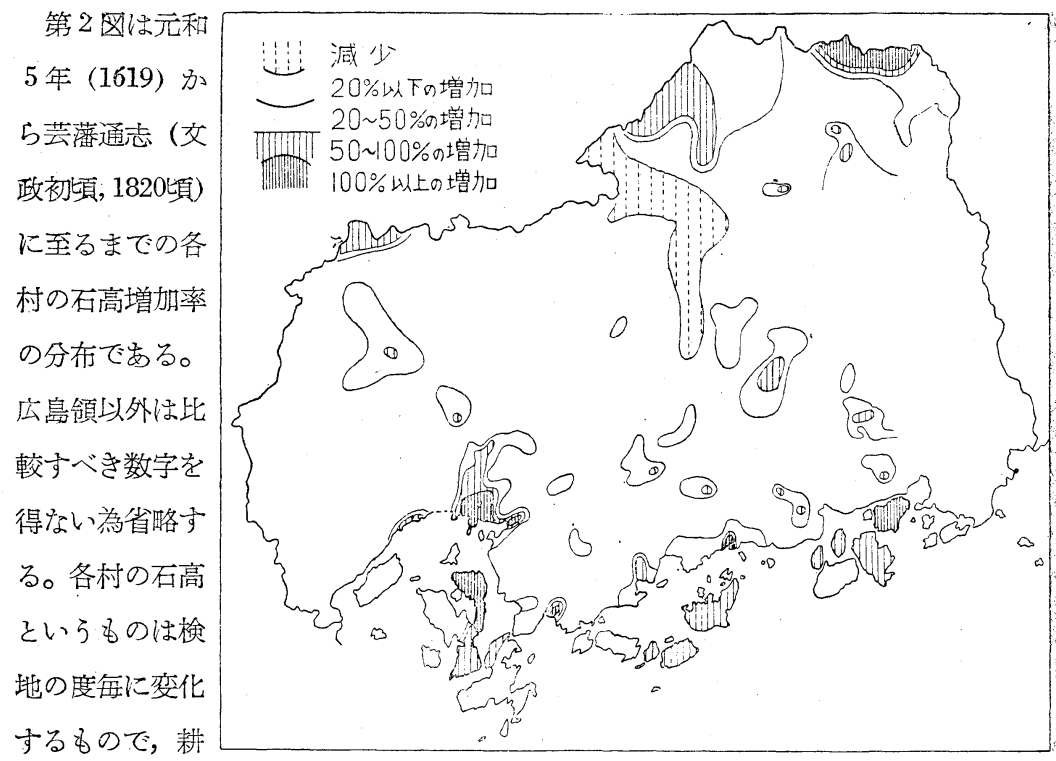

地面積が增加し

第2図 石高の堌加（1619～1820)

ても直ちに变化

するものではな

いので，時期的

に或程度ずれが

离るが，田畑の

別や地力の上下

名椹定に入れて

あるので，土地

生産力のより適

確な表現と考え

られる。この 200

年間において石

高の増加はどの

ような地域にお

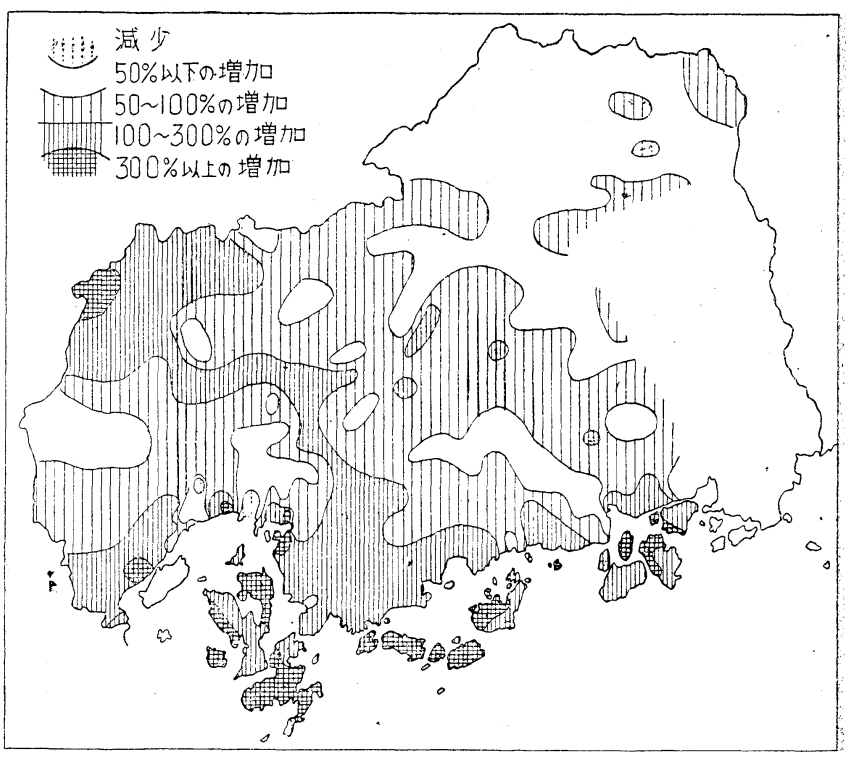

第3図 耕地の増加（1820～1921） 
こったであろろか。石高が 100\%以上増加した所は広島・海田・広・竹原の四ヶ所で

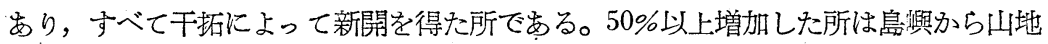
にかけて散在しているが，くわしく見るとこれも，干拓や河川の改修によって水田の 得られた所に多い。大田川下流が石高を増加しているのは河川改修の結果であり，向 島・因島などは干坧によるものである。竹原・向島・五日市等の石高増加には干拓に よって塩浜をつくったことも大いに笴与している。双三郡の西部にまとまって減石し た地域があるがこれは多分川荒れによるものであろろ。中国山地の狭い陕谷を下流に もつ江川が，上流に㕠々洪水による冠水の害をあたえることは現在も同様である。稆 梁山地にも開発が進んでいる状態は明かであるが，開発の重心が沿岸部にあることは 明瞭である。

第 3 区は芸藩通志（交政初頃1820頃）から大正10年（1921）に至るまでの耕地増加 率の分布である。これでも旧広島藩以外の地域は省略した。主として明治時代を中心 とする百年間の耕地増加である。この時代は日本の第一次産業革命の時期を含んで就 り，広島県でも一部に都市化・工業化がかなりみられた。広島市もこの時期に庆午新 開，宇品新開を開いたのであるが耕地面積は減少している。第 2 図にみたように著し い石高の増加を示した沿岸の干拓地はこの特期には多かれ少かれ都市化が行われ，耕 地面積の増加はかえつてその周辺よりも少いという場合が多い。大田川の川筋のよう な所は耕地が近世において既に充分開発されていた為か，第 3 四においては周囲の山 地よりも増加率が低くなっている。沼田川・可愛川等でも同様のことはいえる。この 時期において耕地面積が 100\%以上の增加を示したのは山県郡西部の山地，佐伯県南 部の山地, 安芸郡陸地部南部, 賀茂郡・豊田郡㳂岸部等である。厳島を除く島嶼部全 部 100\%以上の増加率を示し，部分的には 300\%以上即台耕地面積が 4 倍以上になっ た所る多い。この時期における土地開発の重心は明かに島嶼部にある。陸地部におい ては近世において停滞状況にあった所に土地開発が進展している。

第 2 図と第 3 図とを比較すれば近世における農業生産の停滞と明治期における発展 とを容易に対照し得るであろろ。細かく見ればその地域による発展が時代的なずれを 示していることを知り得るであろら。

大正10年 (1912) 以後, 昭和22年 (1947) に至るまでの耕地の増加した地域を示し さのが第 4 図である。戦後の耕地面積の数字は一般に低く見積られているということ 


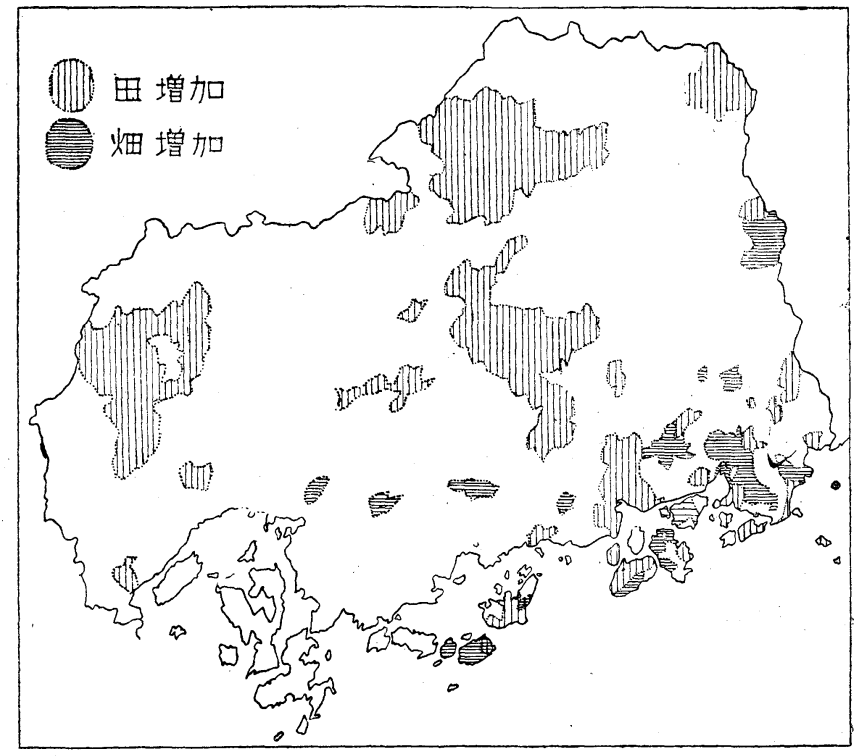

第4図 耕地の増加（1921～1947）
であり，比較す るのは少し不適 当であるが，そ らいう条件を考 えに入れても増 加を示す地域は 或はより一層の 増加を見た地域 であるか子知れ ない。この図に よって耕地の増 加が現在どの地 域に進行してい るかということ が分る。侗この

図においては田の増加した地域・畑の増加した地域・両者共増加した地域を区分して 示した。この図においては耕地の蔵少が広範な地域を占めているのであるが，この中 には数字面だけの減少も主ることを考慮しても，或程度は実際の減少を示すものでも り，耕地の増加が現在の扏術の段階に扎いて限度に達して いること及び都市化・工菜化によって積極的に耕地が減少 せてめられていることを読みとり得る。

3 人口の増加近世に护る人口の増加を地域的な 分布図として示し得る資料は現在見出し得ない。浅野図 畫館にもったといわれる正徳 5 年広島領内戸口調查畫等の 記録があれば與味ある結果を得ると思うのであるがしかた がない。福山領げけを宝永 8 年 (1711) と交化13年(1816) とを比較しその増加率の分布図をつくると第 5 四になる。 山地部に減少・沿岸部に增加していることがはっきり分る。 沿岸部でも松永附近・浦崎・百島・横島・福山附近の增加

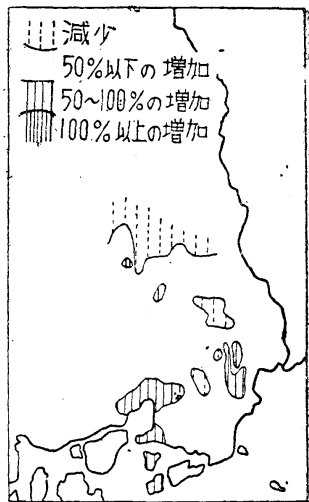

第5図人口の增加 1711〜1816（福山領 のみ) 
は50\%を超えている。広島領についても同様の状態を示したものと思われる。広島領 にふいて各種の資料より得た数字を第 1 表に示する第 1 表によっても㳂岸部島嶼部の 人口の著しい増加を知り得るであろろ。近世における人口の堌加は大体土地の開発を 平行しているといえるようであるが，商業都市として発展してゆく所では土地開発は 人口集積にとって第 2 義的な地位になる。このことは明治期になると更に著しい。

第 6 図は広島領は芸藩通志（交政初頃，1820頃）福山領は文化13年（1816）からい ずれも明治21年 (1888) に至る人口堌加率の分布図で殊に㳂岸部島嶼部の人口堌加と 備後北部の人口堌加が著しい。この時期は都市においても新與の都市と古い都市とが 入れかわりを示した時期で，尾道・三原などの人口堌加は比較的低い。新興の都市と いっても未だ工業的発展は見られず，主として商業的なるのである。農村においても 封建的な制限が解けて新しい発展時期に入った所もあり，旧福山領の山地部も人口増 加に転じている。しかし一般的には次の第 7 図に見るような産業革命期的人口移動は 見られない。土地開発と人口の増加とも特に平行的な関係は見られないが，一部では 人口の増加が新しい土地開発を促した様子もある。

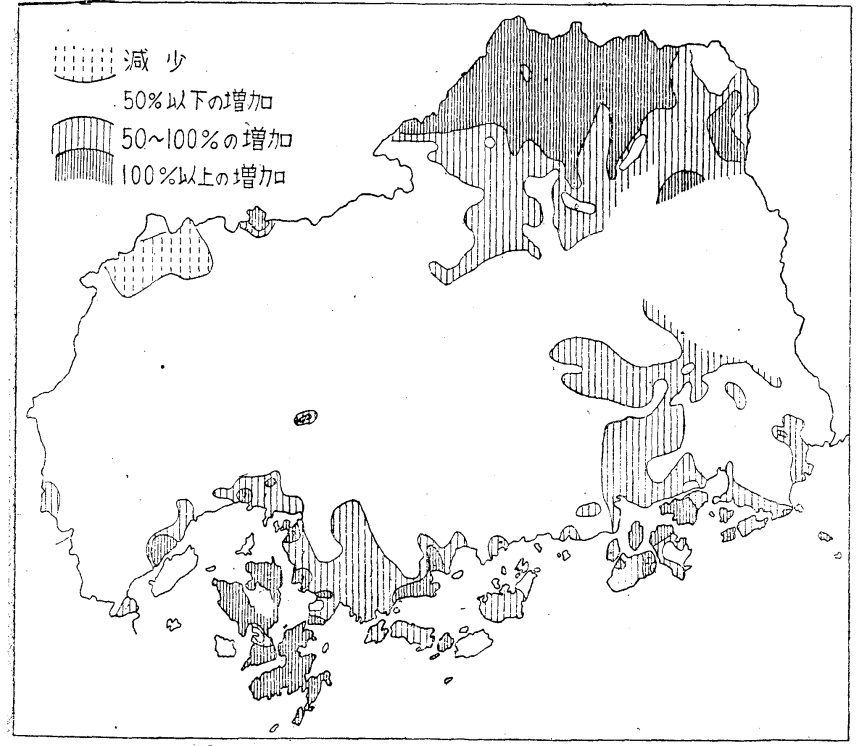

第 6 図人口の增加 $\left(18^{16} / 2_{0} \sim 1888\right)$
第 7 図は明 治21年(1888) 加与大正 9 年 （1920）に至 る人口增加率 の分布図で， 産業革命期に 款る人口給 源としての地 位をはっきり 示し，人口減 少地域が著し く広範な地域 を占めている。

この㭙期においても土地開発は部分的に進捗し，その部分ではわ゙ずかに人の減少を 


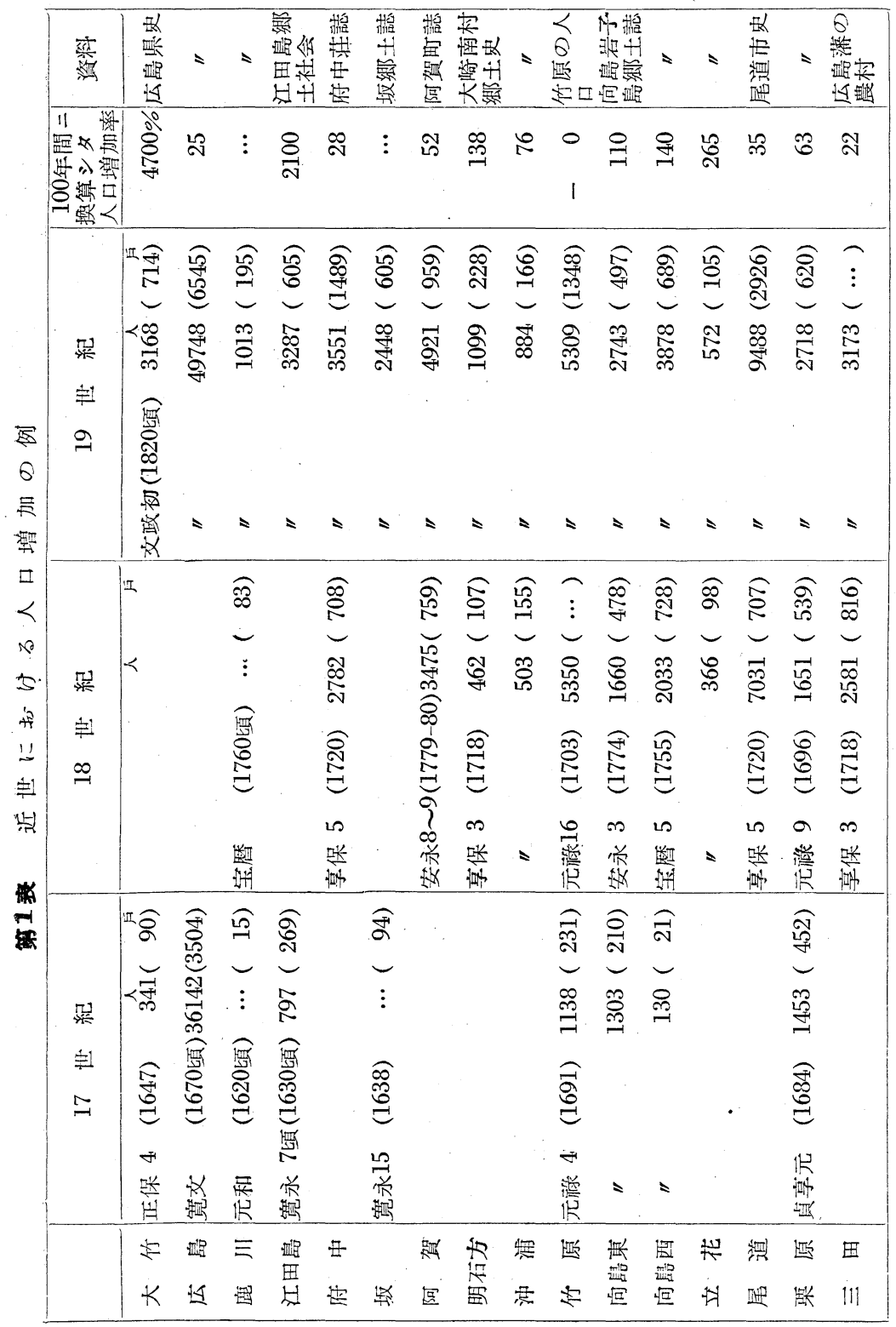




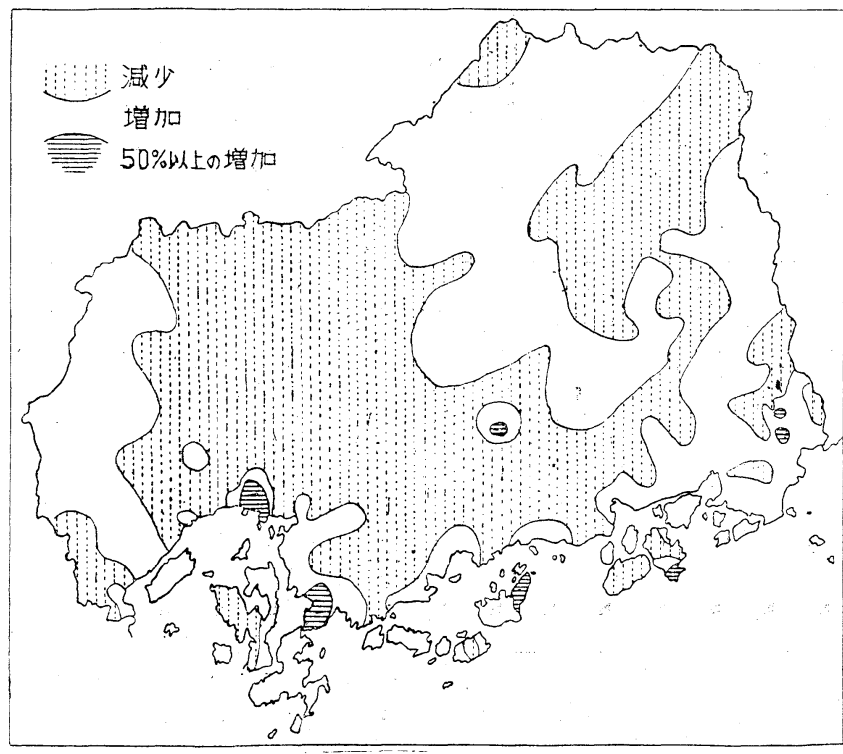

第7図人口の増加（1888～1920）
免れている。

一般的には人 ロの増加と土 地開発とは殆 ど無関係とな り, 全国的な 経済構造の変 化が広島県の 人口増加或は 減少を支配し ているといえ る。

大正 9 年 $(19$ 20) 以後のセ ンサスの完潇 した時代の人口増加或は減少の地域分布についてはこ〉では省略するが，それと土地 開発との関係も第7罒に示されていることと略々同様であり，たら゙こんどの戦争によ る大きな人口移動がエピソーディクなるのとして插入されるであろう。

結び 個別的な集落の土地開発を研究する前提として県全体の地域をとってそれ を概観した。

1 集落の成立は内陸部では中世以来のものが殆どであるが，沿岸部島嶼部には近 世以後のものが多くなる。

2 石高・耕地面積の増加より見たる土地開発の重心は近世には治岸部に，明治期 には島嶼部にある。

3 人口の増加は土地開発の進展と平行する状態から漸次商業的な要因, 工業化・ 都市化の要因によることが大きな比重を占める状態にかわってくる。産業革命期には 全国的な経済構造の变化による人口移動が人口の増加或は減少安支配する。しかし土 地開発の進行する地域では第二義的ではあるが人口は増加傾向にある。

（参考交献）西村嘉助; 広島県の火耕地名 人文地理 $4 の 3($ 昭 27$) 。$ 関山直太郎; 近世日本人口の研究(昭 22$) 。$ (広島大学教育学部助教授) 
remove opposite to the above is done only as a ruler. The living standard of the burning cultivators is lower than that of the plain-farmers. Only freedom permitted there it not to be deprived of their products.

\section{Land Cultivation in Hiroshima Prefecture}

\section{By Kasuke Nishimura}

I studied the outline of the land cultivation in Hiroshima Prefecture afte Edo era by the several maps. The first map : Formation of the new settlement. The second map: Increase of the cultivated land from 1619 to 1820. The third map: Increase of the cultivated land from 1820 to 1921. The forth map: Increase of the cultivated land from 1921 to 1947 . The fifth map: Increase of population from 1711 to 1816 (eastern part of Hiroshima Prefecture). The sixth map: Increase of population from 1816 (or 1820) to 1888. The seventh map: Increase of population from 1888 to 1920.

By these maps I could have got the following conclusion.

1. The new settlements developed after Edo era are distributed in the seashore and islands districts.

2. The cultivated lands increased on the seashore district in Edo era and in the islands district in Meiji era.

3. Before population had increased running with increase of cultivated lands, but recently its increase has been caused by the development of commerce and industry, and the development of cities. That is, development of economic system in Japan has caused the population movement. However, after the War-termination especially, population increase is found in those areas where the cultivated land has increased.

\section{The Boundary of the Lake in Japan}

\section{By Masami Hayashi}

1. There are two types of the boundary of the lake; that is one is what divides the lake into several parts, the other is what is monopolized by only one village or town. As the latter instance, I take the lake of Koya- 